\title{
Strategies of a revenue district in improving its Tax Collection and Compliance
}

\author{
Jane S. Pataueg, Rosalie C. Alejo, Marivic C. Gante, Ma.Rosario M. Bolagao, \\ Ma. Cassandra H. Santos, Marilou P. Pascual
}

\begin{abstract}
The study was conducted on one of the Revenue District Offices in Nueva Ecija. Thirty (30) revenue officers specifically assigned in assessment, collection, client support and compliance section and twenty (20) taxpaying public served as respondents of the study. "It is the Bureau's mandate that they shall comprehend the assessment and collection of the national taxes, fees, and charges, and the enforcement therewith, including the execution of judgments in all cases, decided in its favor by the Court of Tax Appeals and the ordinary courts [1]". The researchers found out that the strategies of the Revenue District were very effective and recommended that the strategies of the office should be continued the way and manner on how they provide tax collection, as well as maintaining the activities that help the revenuers meet their collection goals in the district.
\end{abstract}

Keywords - Tax, Tax Administration, Assessment, Revenue, Collection.

\section{INTRODUCTION}

The Supreme Court of the Philippines has stated that it is axiomatic in the law of taxation that taxes are the lifeblood of the nation [2]. For many years, the truth and significance of this declaration remain unchallenged and is upheld even in times of prosperity and recession. For this reason, "the mission statements of virtually all tax authorities are crafted to highlight the mandate of collecting taxes for and at the least cost to the government, in order to provide sufficient funds with which nation's economy may be sustained and developed [3]". In this light, it has become the enduring goal of every tax authority, be it one that serves a developed or developing nation, to seek and implement strategies and technologies that shall support the continuing improvement of their collection system [3].

There are several government agencies in charge of collecting taxes and fees but the agency contributing the biggest share is the Bureau of Internal Revenue (BIR) [4]. Thus, the ballooning budgetary deficit is always blamed on the inefficiencies of this agency to collect the necessary revenues needed to augment the expenditures of the government. Several laws have been introduced and enacted by the legislature to come up with a sound and feasible system of taxation. Time and again, there seems to be an outcry from the taxpaying public for a fair, just and reasonable manner of taxation, especially the wage earner. It is obvious that the imposition of tax on this group is strictly implemented and monitored compared with those engaged in business.
Any government must be equipped with the necessary machinery to be able to apply the power to tax effectively and squarely. With the fast-changing world of taxation, with the advent of globalization and with the continuous introduction and development of information technology, the BIR's machinery must be competent enough to face the challenges of adopting and implementing the most sound and efficient tax administration

For the past years, revenue collection of the BIR comparatively increased, yet it hardly meets an extremely large amount of collection goal assigned by the National Economic Development Authority. The BIR attributed this shortfall to several factors like unfavorable business climate (brought about by the regional currency crises), high-interest rates which resulted to either downsizing or closing shops of a lot of business establishments, decrease in volume of transactions from sale of properties of the massive tax credit scam which had deprived the government of millions of pesos in revenues [5].

In one of the districts of Nueva Ecija, one office strictly implemented the revenue regulations and orders to the taxpaying public within their area. The researchers analyzed and evaluated the effectiveness of the district's strategies and activities to maintain their collection goals.

\section{METHODOLOGY}

This study used a descriptive research design. According to [6], as cited by the authors in [7] and [8], 'descriptive research systematically describes a situation, problem, 
phenomenon, service or program, attitude toward an issue or simply, it provides information on a subject". This study described the analysis of one of the district offices in Nueva Ecija on its tax collection and compliance. The respondents of the study were chosen purposively based on the following criteria [9]: they must be a revenue officer and taxpayer within the area covered by the said district office, at least two years working as a revenue officer and 1 year as the taxpayer who is consistently paying his tax obligations. The picked respondents were thirty (30) revenue officers specifically assigned in assessment, collection, client support and compliance section and twenty (20) taxpaying public. The data came from the researchers-made questionnaire answered by the respondents. The study was done from January 2019 to October 2019.

\section{RESULTS AND DISCUSSION}

\section{Internal Factors Evaluation}

Table 1 shows the internal factors that the researchers gathered when they asked the respondents which have a greater effect on their performance.

Table 1. Internal Factor Evaluation

\begin{tabular}{|l|c|c|}
\hline Key Internal Factor & Weighted Mean & Verbal Interpretation \\
\hline $\begin{array}{l}\text { 1. All revenuers assigned are CPA's; some are CPA lawyers; some are } \\
\text { with MBA (for Non-CPA revenuers) }\end{array}$ & 3.80 & Strongly Agree \\
\hline $\begin{array}{l}\text { 2.Improved technology through the Integrated Tax System and online } \\
\text { payment system(computerization) }\end{array}$ & 3.40 & Strongly Agree \\
\hline 3. Management is oftentimes influenced by incumbent politicians & 3.23 & Strongly Agree \\
\hline 4.Inadequate funds for the completion of Tax Computerization Project & 3.16 & Strongly Agree \\
\hline $\begin{array}{l}\text { 5. Old employees, with ages ranging from 45 to 60, are no longer willing } \\
\text { to undergo career improvement and changes }\end{array}$ & 3.26 & Strongly Agree \\
\hline Overall Weighted Mean & & Strongly Agree \\
\hline
\end{tabular}

The table for internal evaluation revealed that the respondents strongly agreed $(\mathrm{WM}=3.80)$ that all revenuers assigned are CPAs, lawyers and with Masters in Business administration. This means that the personnel is qualified in their respective jobs. The lowest weighted mean as rated by the respondents was funding for the completion of the tax computerization project. This implies that for the project to be completed, additional funds should be secured by the district.

\section{External Factor Evaluation}

Table 2 shows the external factors gathered from the respondents that can be an important factor in the success of the Bureau on its tax collection and compliance. The table shows that still its success basically conforms with information technology. However, they have the least rating as to the needed enactment of the new law that will be passed by Congress.

Table 2.External Factor Evaluation

\begin{tabular}{|l|c|c|}
\hline \multicolumn{1}{|c|}{ Key External Factors } & Weighted Mean & Verbal Interpretation \\
\hline 1.Information technology & 3.40 & Strongly Agree \\
\hline 2.The enactment by Congress of new tax laws & 2.58 & Agree \\
\hline 3. Tax cheats/Tax evaders & 3.18 & Strongly Agree \\
\hline 4. Political backings and influences & 3.22 & Strongly Agree \\
\hline 5. Unstable economy & 3.17 & Strongly Agree \\
\hline Overall Weighted Mean & 3.11 & Strongly Agree \\
\hline
\end{tabular}




\section{Strategies and Activities of the Revenue District Office}

Table 3. Strategies and Activities of the Office

\begin{tabular}{|l|c|c|}
\hline \multicolumn{1}{|c|}{ Key External Factors } & Weighted Mean & Verbal Interpretation \\
\hline 1. Improved tax return filing and tax payments through the internet & 3.70 & Strongly Agree \\
\hline $\begin{array}{l}\text { 2. Offer continuing education through seminars and updates on both } \\
\text { information technology and Tax Laws }\end{array}$ & 3.30 & Strongly Agree \\
\hline $\begin{array}{l}\text { 3. Offering Tax Amnesty on qualified taxpayers in accordance to the } \\
\text { Revenue Regulations }\end{array}$ & 3.44 & Strongly Agree \\
\hline 4. Strict monitoring of tax evaders through surveillances and mapping & 3.50 & Strongly Agree \\
\hline $\begin{array}{l}\text { 5. Full-blown publication about the tax obligation of the taxpayers } \\
\text { available on the website. }\end{array}$ & 3.65 & Strongly Agree \\
\hline $\begin{array}{l}\text { 6. Seminars were regularly given to taxpayers to educate them on the } \\
\text { updates and other regulations. }\end{array}$ & 3.52 & Strongly Agree \\
\hline Overall Weighted Mean & 3.52 & \\
\hline
\end{tabular}

The respondents strongly agreed that the very effective strategy is the filing of the tax return and tax payments using the internet $(\mathrm{WM}=3.70)$. Other strategies that they believed were effective were "full-blown publication about the tax obligation of the taxpayers available on the website $(\mathrm{WM}=3.65)$ ", "seminars are regularly given to taxpayers to educate them on the updates and other regulations (WM=3.52)" and "strict monitoring of tax evaders through surveillances and mapping $\mathrm{WM}=3.50$ )".

The lowest weighted mean is to offer continuing education through seminars and updates on both information technology and Tax Laws $(\mathrm{WM}=3.30)$, which implies that revenuers should also be equipped with proper guidelines and continuous education for the betterment of the Bureau.

\section{CONCLUSIONS AND RECOMMENDATIONS}

The lowest average in the internal factors is inadequate funds for the completion of the Tax Computerization Project. In external factors, it is the enactment by Congress of new tax laws and among the strategies and activities the lowest weighted mean is offer continuing education through seminars and updates on both information technology and Tax Laws. In light of the above, the following recommendations where drawn: 1 . To upheld the continuing professionalization of the employees thereby promoting personal and career development in terms of skills, knowledge and moral values and to improve the public's perceptions of the Bureau. 2. To increase tax collection by strictly going through tax evaders and tax cheats and improve and increase collection resulting from exhaustive examination, audit and investigation of tax liabilities of various taxpayers. 3. To cope with the continuing development in the field of information technology, continuously implement and practice auditing through and around the computer. To achieve the desired speed and accuracy in obtaining data and to monitor all transactions made by the taxpayer in the Bureau. 4. Request for sufficient budgetary allocation to finance compensation package and benefits of employees and for the completion and improvement of the Tax Computerization Project such as improved tax return and online payment system 5. Creation of Special Task Force to strengthen the linkage of Bureau with other government offices.

The strategies are all relevant and necessary for the effective collection and tax administration functions of the bureau. However, these are impossible to implement simultaneously considering that an additional budget is needed to undertake all of these. Management may have the same things in mind to improve the performance of the agency but due to reasons beyond their control, they cannot do what can be done. The most important strategy that needs to be acted upon is the request for allocation of sufficient budget for compensation package and benefits of employees and for maintenance of technology development.

Lastly, as cited by the authors in [10] research on the same discipline with more respondents should be conducted be able to make accurate decisions given much available data or information [11] to further validate the findings of this study.

\section{REFERENCES}

[1] BIR.gov.ph. BIR Mandate, Philippine Transparency Seal.www.br.gov.ph

[2] Foulkes, A. (2011). Foundation for Economic Education. Retrieved from http://fee-org.cdn 
[3] Aguirre, E.(n.d.).THE PHILIPPINE TAX COLLECTION SYSTEM Its Evolution and Direction.https://edoc.pub/thephilippine-tax-collection-system-pdf-free.html

[4] Cluster and Agencies (2019). Retrieved from http://www.dof.gov.ph

[5] Yap, J. (1996). Inflation and Economic Growth in the Philippines. Retrieved from http://dirp4.pids.gov.ph.Report on Economic and Financial Development -BSP. Retrieved from http://www.bsp.gov.ph

[6] Kumar, R. Research Methodology: A step-by-step guide fro beginners $\left(4^{\text {th }}\right.$.ed.) SAGE,CA:Thousand Oaks.2014

[7] Subia, G.S., Trinidad, C.L., R.R., Medrano, H.B. \& Manuzon, E.P. Learning Styles and Preferred Teaching Styles of Master of Arts and Teaching (MAT), major in Vocational Technological Education (VTE) Generation Y Learners, International Journal of English Literature and Social Sciences (IJELS) Vol-4, Issue 2, Mar-Apr, 2019. https://dx.doi.org/10.22161/ijels.4.2.35.

[8] Jocson, J., Florencondia, N. and Subia, G. (2019). Flood Prevention and Mitigation Initiatives towards a Flood-Free City. American Scientific Research Journal for Engineering, Technology, and Sciences (ASRJETS) (2019) Volume 58, No 1 , pp 215-224.

[9] Subia, G. (2018) Comprehensible Technique in Solving Consecutive Number Problems in Algebra. Journal of Applied Mathematics and Physics, 6, 447-457. Doi:10.4236/jamp.2018.63041.

[10] Ron Alvin E. Rodriguez, Israel R. Blancaflor, Rex Christopher G. Encabo, Dr. Noel Florencondia, Dr. Gener Subia(2019).Correlation between Load Growth and Reliability of an Electric Service Cooperative in the Philippines. International Journal of Advanced Engineering, Management and Science (ISSN: 2454-1311),5(8), 509-511. http://dx.doi.org/10.22161/ijaems.58.5

[11] Subia, Gener S. (2018). Think Like My Teacher (TLMT): A New Method in Assessing Millennial Learners. International Journal of Arts, Humanities and Social Sciences. Volume 3.Issue 1.www.ijahss.com 